\title{
"Dream of a Shade": Refractions of Epic Vision in Pindar's "Pythian 8" and Aeschylus' "Seven against Thebes"
}

\section{Citation}

Nagy, Gregory. 2000. “'Dream of a Shade': Refractions of Epic Vision in Pindar's 'Pythian 8' and Aeschylus' 'Seven Against Thebes."' Harvard Studies in Classical Philology 100: 97-118. doi:10.2307/3185211.

\section{Published Version}

$10.2307 / 3185211$

\section{Permanent link}

http://nrs.harvard.edu/urn-3:HUL.InstRepos:15786568

\section{Terms of Use}

This article was downloaded from Harvard University's DASH repository, and is made available under the terms and conditions applicable to Other Posted Material, as set forth at http:// nrs.harvard.edu/urn-3:HUL.InstRepos:dash.current.terms-of-use\#LAA

\section{Share Your Story}

The Harvard community has made this article openly available.

Please share how this access benefits you. Submit a story.

\section{Accessibility}




\section{"Dream of a Shade": Refractions of Epic Vision in Pindar's Pythian 8 and Aeschylus' Seven against Thebes Gregory Nagy}

[[This is an electronic version of an article that appeared in Harvard Studies in Classical Philology 100 (2000) 97-118. In this online version, the original page-numbers of the printed version are indicated within braces (" $\{$ " and "\}"). For example, "\{97|98\}" indicates where p. 97 of the printed version ends and p. 98 begins.]]

This essay explores the idea of epic in relative rather than absolute terms, with specific reference to the image of a "dream of a shade" in Pindar's Pythian 8 and Aeschylus' Seven against Thebes. ${ }^{1}$ In both form and content, these two poetic creations contain features that may be described as epic in nature. The main argument of this essay is that such features, as refracted separately in the two distinct genres of tragedy and victory ode or "epinician," are in fact complementary in revealing a unified picture of epic as a genre in its own right. ${ }^{2}$

The problem is, we cannot even begin to piece together such a picture without a clarification of the idea of epic as a genre. So I offer this premise: that the genre of epic, as well as any other genre, cannot be defined absolutely, as if it belonged to Plato's world of Forms (in the usage of Plato, the very idea of "Form" is expressed by the same word that means "genre":

\footnotetext{
${ }^{1}$ A point of convergence is seen by J. H. Finley, Pindar and Aeschylus (Cambridge MA 1966) 245: "In Pythian 8 Amphiaraus watching the young Alcmaeon from the grave feels only the beauty of his heroism though he knows him destined to die. Eteocles' beauty in the Septem is more clouded, and the dry eyes of the Labdacid curse watching beside him declare a human inheritance from which peace is far removed." I evoke his shining words as I dedicate this essay to his memory.

${ }^{2}$ On the optic metaphors of refraction, with special reference to the poetic image of refrain (from Latin refringere), see G. Nagy, Poetry as Performance: Homer and Beyond (Cambridge 1996) 23-24.
} 
eidos). ${ }^{3}$ Rather, genre needs to be defined both $\{97 \mid 98\}$ historically - as it existed at a given time - and comparatively in relation to any other coexisting genres at that same given time. ${ }^{4}$

This essay, then, offers preliminaries to a reconstruction of the genre of epic as it existed in the first half of the fifth century BC, roughly the era shared by Aeschylus and Pindar, with specific reference to two other genres, tragedy and epinician, as represented by Aeschylus' Seven against Thebes (originally presented in $467 \mathrm{BC}$ ) and Pindar's Pythian 8 (originally presented in $446 \mathrm{BC}$ ). I will begin by considering in the most general terms the relationship of epic to the tragedies of Aeschylus and the epinicians of Pindar. Then I will proceed to examine specific features of the Seven against Thebes and Pythian 8 that complement each other in refracting an essential feature that typifies epic. That feature is the self-image of epic as a poetic vision.

In the case of Aeschylus, I suggest that we start by adopting a comparative perspective in considering the performances of his tragedies by professional actors (and by nonprofessional choruses) at the Athenian state festival of the City Dionysia - in light of the corresponding performances of the Homeric Iliad and Odyssey by professional rhapsodes at the Athenian state festival of the Panathenaia. ${ }^{5}$ Granted, information about the seasonally recurring Panathenaic

\footnotetext{
${ }^{3}$ See especially Plato Laws III 700b on the eidē 'genres' of humnoi, thrēnoi, and so on. Cf. Nagy, "Epic as Genre," Epic Traditions in the Contemporary World: The Poetics of Community (eds. M. Beissinger, J. Tylus, and S. Wofford; Berkeley and Los Angeles 1999) 21-32, especially p. 29n22.

${ }^{4}$ L. Slatkin, "Genre and Generation in the Odyssey," MHTIC: Revue d'anthropologie du monde grec ancien 2 (1987) 259-268, especially p. 260.

${ }^{5}$ See Poetry as Performance p. 81 for more on the "functioning institutional complementarity, in Athens, between the performance of drama by actors and chorus at the City Dionysia on the one hand and, on the other, the performance of Homeric epos - and of Homeric hymns that serve as preludes to the epos - by rhapsodes at the Panathenaia." The most important references to the Athenian institution of rhapsodic performances of Homeric poetry at the Panathenaia are "Plato" Hipparkhos 228b-c, Lycurgus Against Leokrates 102, and Dieuchidas of Megara (4th century BC) FGH 485 F 6 via Diogenes Laertius 1.57. For a correlation of the information provided by these passages, see Poetry as Performance pp. 70-91. As for the references to the epe of Homer, as found in all three passages, I offer the working translation 'verses'. More precisely, the epe are the poetic 'lines' of Homer (on epos as a distinct poetic unit or 'line', see H. Koller, "Epos," Glotta 50 [1972] 15-24). For Aristotle, the epe of Homer become 'epic' by default, whence the term epopoiia 'making of epic', as in the beginning of the Poetics, 1447a: see "Epic as Genre" p. 27. The implicit preoccupation with 'lines' as the poetic units or building blocks of epē has to do with an ongoing question that engaged the ancient transmitters of the Homeric tradition: which 'lines' are genuine
} 
performances of Homeric poetry is sparse, and there are many uncertainties: we cannot even be $\{98 \mid 99\}$ certain about the actual form of the Iliad and the Odyssey as they would have been performed during the first half of fifth century in Athens, let alone elsewhere. ${ }^{6}$ Still, among the few surviving certainties we do find one that turns out to be vital for understanding the overall history of the Homeric tradition: the Iliad and the Odyssey eventually became the only epic poetry to be performed by rhapsodes at the Panathenaia, that most important of all Athenian festivals. ${ }^{7}$ To put it negatively: other $\{99 \mid 100\}$ epic traditions, known under the general heading of the "Cycle," were eventually excluded from the official rhapsodic

compositions of Homer and which 'lines' have been 'interpolated' (one word for which is emballō, as in Diogenes Laertius 1.57)? For more on this specific concern, see the next note.

${ }^{6}$ We find essential pieces of information in the ancient commentaries on Pindar Nemean 2.1 as preserved in the scholia (ed. A. B. Drachmann, Scholia Vetera in Pindari Carmina I-III [Leipzig 1903-1927]). This information, I argue, was mediated by the school of Aristarchus (middle of 2nd century BC), whose thinking affects an important reference to Hippostratus, = FGrH 568 F 5, in the scholia to Nemean 2.1c. Hippostratus (ca. 3rd century BC) is being cited here as the source for information concerning Kynaithos of Chios as the first rhapsodic performer of the epe of "Homer" in the polis of Syracuse, within the time-frame of the 69th Olympiad (= 504-1 BC). It seems to me misleading to claim that all the information we read in the scholia about the rhapsodic performance of Kynaithos "derives" not from Aristarchus but from Hippostratus, as if we needed to make an exclusive choice between the two sources. R. Janko makes this claim in his review of I. Morris and B. Powell, eds. (A New Companion to Homer [Leiden 1997]), Bryn Mawr Classical Review 98 (1998) 5.20 (with specific reference to my chapter "Homeric Scholia," pp. 101-122, where I discuss the scholia to Pindar Nemean 2.1c). The fact that one detail in the scholiastic information about Kynaithos (that is, the dating of his rhapsodic performance at Syracuse) "derives" from Hippostratus cannot be used to rule out the school of Aristarchus as an intermediary source for that information or even as a direct source for other information about Hippostratus. Besides the reference to Hippostratus in the scholia for Pindar Nemean 2, we see four explicit references to Aristarchus in the scholia for the same poem: 9a, 17c (twice), and 19. We may note too the reference to Hippostratus FGrH 568 F 2 in the scholia for Pindar Pythian 6.5a, which happens to occur immediately next to an explicit reference to Aristarchus, again at 5a. In all, we find over seventy references to Aristarchus in Drachmann's edition of the Pindaric scholia (and five to Hippostratus). These references, as casual as they are frequent, lead me to conclude that Aristarchus' overall critical presence was taken for granted in the Pindaric exegetical tradition that culminated in the scholia. Returning, then, to the scholia for Pindar Nemean 2.1c: I maintain that the learned discussion in this section reflects primarily the agenda of Aristarchus, not of Hippostratus (whose work concentrated, after all, on sorting out the genealogies of Sicilian dynasties). Thus I follow the view of F. A. Wolf, Prolegomena ad Homerum (Halle 1795) ch. 25, who discerns the agenda of "the Alexandrians" in the claim, reported by the scholia for Pindar Nemean 2.1c, that Kynaithos and his followers 'interpolated many of the epe that they had created into the creation [poetry] of Homer' (oú $\varphi \propto \sigma r$

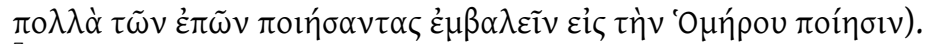

${ }^{7}$ The wording of Lycurgus Against Leokrates 102 makes it clear that only the epe of "Homer" are performed at the Panathenaia. Also, in the scholia to Pindar Nemean 2.1d ed. Drachmann, it is mentioned en passant that the

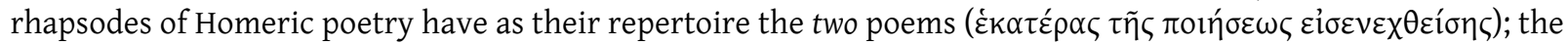
source of information in this context is named: Dionysius of Argos (ca. 4th or 3rd century BC) = FGH $308 \mathrm{~F} 2$. In my view, this reference to Dionysius was mediated by the school of Aristarchus; compare the reference to Hippostratus (ca. 3rd century BC) = FGrH 568 F 5 in the scholia to Pindar Nemean 2.1c, as discussed in the note above. 
repertoire of the Panathenaia. ${ }^{8}$ Two of the most outstanding examples of such epics were the Thebaid (PEG pp. 20-28, EGF pp. 21-26) and the Epigonoi (PEG pp. 29-31, EGF pp. 26-27). ${ }^{9}$ The alternative epic poetry of the "Cycle," as we can see clearly even from the fragmentary evidence concerning performance traditions sanctioned by the Athenian State in the first half of the fifth century $\mathrm{BC}$, was absorbed into the tragic poetry of the City Dionysia, as in the case of the Seven against Thebes of Aeschylus, which is evidently a tragic version of the epic Thebaid. ${ }^{10}$ To that extent, I would say that tragedy became a kind of neo-epic, though we should $\{100 \mid 101\}$ keep in mind the obvious differences in the earlier historical backgrounds of epic and tragedy. ${ }^{11}$

In the case of Pindar, we may continue to take a comparative perspective as we look at the explicit references in his epinicians to epic as a genre, combined with explicit self-references to the praise poetry of the epinician as a realization or "actualization" of a prototypical

\footnotetext{
${ }^{8}$ On the concept of the "Cycle" in the fifth and fourth centuries BC as the entirety of epic traditions - with the notable exception of the Homeric Iliad and Odyssey, see Nagy, Homeric Questions (Austin 1996) 38. For editions of the "Cyclic" testimonia and fragments, see PEG = A. Bernabé, ed., Poetae Epici Graeci I (Leipzig 1987); EGF = M. Davies, ed., Epicorum Graecorum Fragmenta (Göttingen 1988).

${ }^{9}$ For an appreciation of the epic Thebaid as an esthetic rival of the Iliad and Odyssey, see especially Pausanias 9.9.5. The wording of Herodotus 5.67 suggests that the epic themes of the Thebaid and the Epigonoi may have been the basic repertoire for rhapsodes' performances at the festivals of Argos and Sikyon: see E. Cingano, "Clistene di Sicione, Erodoto e i poemi del Ciclo tebano," Quaderni Urbinati di Cultura Classica 20 (1985) 31-40, with reference to Herodotus 5.67. See also Nagy, Pindar's Homer: The Lyric Possession of an Epic Past (Baltimore 1990) 22n22.

${ }^{10}$ We learn from the hypothesis of the Seven that Aeschylus won first prize in $467 \mathrm{BC}$ with the sequence of these four dramas: Laios, Oedipus, Seven against Thebes, and Sphinx. The close relationship between Aeschylus' dramatic repertoire and the epic repertoire of the "Cycle" is stressed by J. Herington, Poetry into Drama: Early Tragedy and the Greek Poetic Tradition (Berkeley and Los Angeles 1985) 139. I argue further for a complementarity between the "Cyclic" repertoire of the City Dionysia and the "Homeric" repertoire of the Panathenaia. In my view, even the representations of Achilles and Odysseus in early tragedy reflect the generally "Cyclic" repertoire and not the specifically "Homeric" repertoire of the Iliad and Odyssey. In terms of this argument, the "Homeric" Iliad and Odyssey are distinct because they became the sole epics of the Panathenaia. As such, the Iliad and Odyssey would have passed through a distinctly Athenian phase of evolution, not shared by the "Cycle." Elsewhere, I have described the Athenian phase of Homeric poetry as the "Panathenaic bottleneck": see pp. 271-272 of "Irreversible Mistakes and Homeric Poetry," in J. N. Kazazis and A. Rengakos, eds., Euphrosyne: Studies in Ancient Epic and Its Legacy in Honor of Dimitris N. Maronitis (Stuttgart 1999) 259-274.

${ }^{11}$ On epic elements in tragedy, see in general Herington pp. 138-144, the section entitled "Aeschylus Homericus?" I note with special interest his remark at p. 139: "It should not be forgotten that (at least to judge by the Oresteia) the running time of a trilogy could be more than a quarter of that of a full-length epic."
} 
function of epic - to make kleos 'fame'. ${ }^{12}$ These references imply that the genre of the epinician, as inherited by Pindar, is not only older than the genre of epic: more than that, the praise poetry of the epinician is pictured as the compressed origin of epic, which by contrast is pictured as an expanded derivation of praise poetry. ${ }^{13}$ In Pindar Nemean 8.51-52 - to cite the most relevant example - the athletic ordeals of the Seven against Thebes, as virtually celebrated by the genre of the epinician, are privileged as older than their wartime ordeals as actually celebrated by epic (and as attested by the surviving fragments of the epic Thebaid). In other words, the victory ode of Pindar claims that its "praise poetry was praising heroes even before the events recorded by epic."1 ${ }^{14}$ Let me stress again: such self-references imply an even more important claim: that the compressed poetry of praise actually generated the expanded poetry of epic. Such claims, built into the epinician tradition, have a historical validity in the sense that the epinician is in some ways older than the epic in form (for example, in its metrical repertoire) while praise poetry is in general older than epic poetry in function (for example, in its conventions of reference to the present as well as the heroic past) ${ }^{15}$ For the moment, however, questions of historical derivation are irrelevant: the one point of relevance is simply the functional relationship of epinician and epic, as claimed by epinician. To that extent, I would say that the epinician is a kind of micro-epic, though we should keep in mind the obvious differences in the earlier historical backgrounds of epic and epinician.

Proceeding now from the general to the specific, let us explore the $\{101 \mid 102\}$ wording of Aeschylus' Seven against Thebes, as a "neo-epic," and of Pindar's Pythian 8, as a "micro-epic," concerning the overall epic narrative about the Seven against Thebes and their sons, the Epigonoi. In parallel ways, both of these poetic creations picture this narrative as a vision.

\footnotetext{
${ }^{12}$ Nagy, Pindar's Homer pp. 202-214, especially with reference to Pindar Pythian 4.277-279, Isthmian 8.56a-62, and Pythian 6.28-51.

${ }^{13}$ Pindar's Homer p. 437 (summary).

${ }_{14}^{14}$ Pindar's Homer p. 192, with further examples and references.

${ }^{15}$ Pindar's Homer pp. 414-437.
} 
In the Seven of Aeschylus, each of the seven heroes arrayed against the polis of Thebes is visualized directly, by way of direct speech as delivered by the messenger (to Eteocles as the chief defender of the polis); further, the identity of each hero is visualized indirectly, by way of a blazon on his shield, the word for which is sèma 'sign, signal' (lines 387, 404, 432, 491, 518, 591, 643); even further, the semma of each hero is interpreted directly by way of the same direct speech delivered by the messenger. ${ }^{16}$

Similarly in Pindar's Pythian 8, the hero Alcmaeon is visualized directly by way of direct speech as delivered by his father Amphiaraus from the realm of the dead and as "quoted" by the epinician (lines 44-55); further, the hero is visualized indirectly by way of the blazon on his shield, the image of a drakōn 'snake' (line 46); even further, this blazon is interpreted directly by way of the same direct speech delivered by the hero's dead father (lines 44-45). This parallelism of Pindar's Pythian 8 with Aeschylus' Seven is particularly remarkable in view of the epic identity of the hero Amphiaraus: he is one of the original Seven against Thebes and his son Alcmaeon is one of the Epigonoi. The parallel visualizations of Pindar and Aeschylus are conjuring parallel visions emanating from the epic tradition of the Thebaid and the Epigonoi.

In both form and content, Pindar's poetic words "quoting" a dead hero's vision of a living hero are the words of a mantis 'seer', as we can see clearly from the wording of the hero Amphiaraus, who is imagined $\{102 \mid 103\}$ as speaking from the dead when he envisions the blazon on the shield of his son, the hero Alcmaeon:

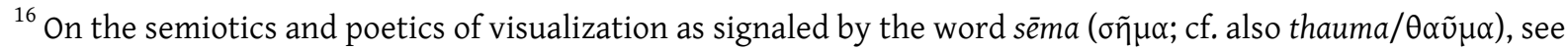
Nagy, Greek Mythology and Poetics (Ithaca 1990) ch. 8, = a rewritten version of "Sēma and Noēsis: Some Illustrations," Arethusa 16 (1983) 35-55. On the semiotics of visualization as deployed specifically in theater, with reference to the blazons or sèmata on the shields of the Seven, see F. Zeitlin, Under the Sign of the Shield: Semiotics and Aeschylus' Seven Against Thebes (Rome 1982), including bibliography on earlier work, especially H. H. Bacon, "The Shield of Eteocles," Arion 3 (1964) 27-38, and P. Vidal-Naquet, "Les boucliers des héros," Annali del seminario di studi del mondo classico: Archeologia e storia antica 1 (1979) 95-118; = "The Shields of Heroes," Tragedy and Myth in Ancient Greece (eds. J.-P. Vernant and P. Vidal-Naquet; translated by J. Lloyd; Sussex and Atlantic Highlands, N.J. 1981) 120149.
} 


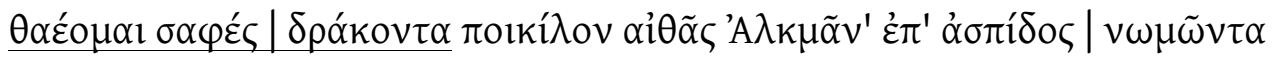

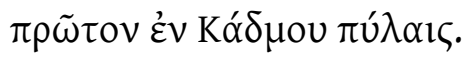

I see [thaeomai] clearly [saphes] Alcmaeon, wielding the patterned [poikilos] snake [drakōn] on his blazing shield, in the forefront of the gates of Kadmos.

Pindar Pythian 8.45-47

Immediately preceding the "quotation" of the actual vision, the interpretation of the dead father's mantic vision is likewise "quoted" by Pindar's song:

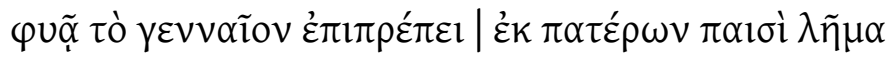

By inherited nature, the noble purpose [lēma] shines forth from fathers [pateres] to sons. ${ }^{17}$

Pindar Pythian 8.44-45

It is relevant that Pindar's song claims to have received as a gift the manteumata 'mantic crafts' (8.60) of the seer Amphiaraus, who had appeared to the poet in an epiphany $(8.56-60){ }^{18}$ Thus becoming mantic in its own right, Pindar's song describes itself as a humnos (8.57) that can now duly reciprocate the mantic gift of Amphiaraus by celebrating Alcmaeon (again, 8.56-60). ${ }^{19}$

\footnotetext{
${ }^{17}$ I have simplified my earlier translation, as printed in Pindar's Homer p. 195.

${ }^{18}$ The voice of the poet says that he "met" the mantic hero on the way to Delphi (Pindar Pythian 8.56-60): that is, the poet himself experienced the vision of a heroic epiphany, which is now the inspiration, as it were, of Pindar's words. The theme of epiphany is connected to the mantic interpretation: 'By inherited nature, the noble purpose [lēma] shines forth from fathers [pateres] to sons' (43-44). It is also connected to what the voice of the poet announce later on, at lines 95-97, which we will consider further below. See also T. K. Hubbard, "The Theban Amphiaraon and Pindar's Vision on the Road to Delphi," Museum Helveticum 50 (1993) 193-203.

${ }^{19}$ This Pindaric association of humnos with the mantic arts of Amphiaraus at Pythian 8.57 may be connected to an epic theme concerning the heroic seer. According to the Herodotean Life of Homer 9 (PEG T 7 = EGF F 9) Amphiaraus himself had once upon a time composed humnoi to the gods which "Homer" later performed

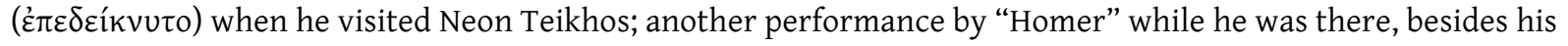
own poetry, was the exelasia of Amphiaraus to Thebes. What particularly interests me about this whole narrative is the idea that epic can appropriate the poetry of the seer.
} 
Earlier, when the words of Pindar introduce the words of Amphiaraus by quoting them directly, the seer is said to speak in ainigmata 'riddles' (ainissomai 8.40: aivíł $\{\alpha 0){ }^{20}\{103 \mid 104\}$

For the moment, let us focus our attention on the collocation of theaomai (Doric thaeomai) with saphes 'clearly' in Pindar Pythian 8.45, where the sense of the word saphēs 'clear' conveys the visual clarity of mantic clairvoyance. The same clairvoyant sense is conveyed in the three occurrences of the same word saphēs in Aeschylus' Seven against Thebes:

Line 40, near the beginning (second verse) of the messenger's initial speech:

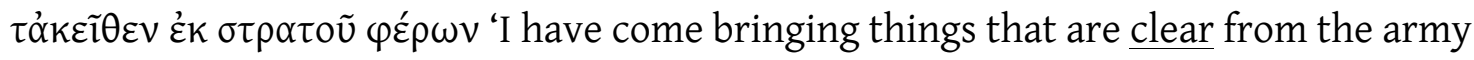
back there'; the messenger describes himself as a 'viewer', katoptēs, of the things happening there (line 41).

Line 67, at the second-to-last verse of that same speech: the messenger refers to the

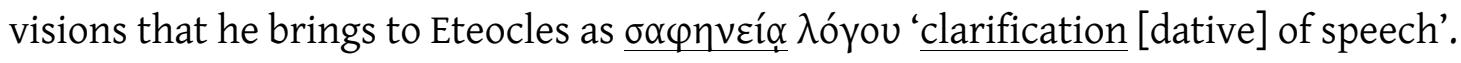

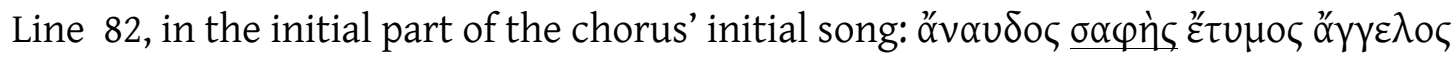
'the clear and genuine messenger' (with reference to the chorus' actual vision of the dust rising toward the aether, as a sign of the oncoming doom). ${ }^{21}$

Moreover, the messenger's mantic visions had been preceded, as the words of Eteocles make

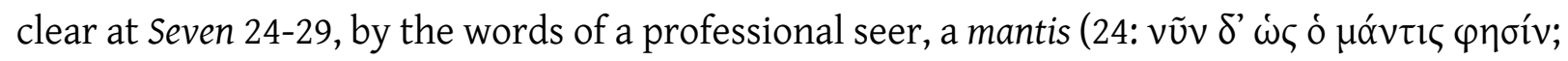
27: $\left.\mu \alpha v \tau \varepsilon v \mu \alpha \alpha^{\tau} \omega v\right)$, who had already interpreted for Eteocles the omens of birds that

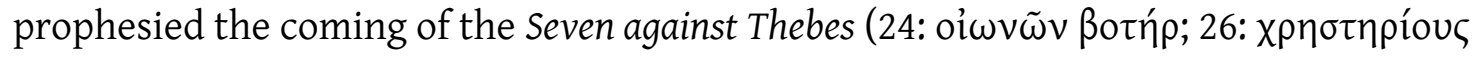
öpvil $\theta \propto \varsigma){ }^{22}$

\footnotetext{
${ }^{20}$ Cf. Sophocles Epigonoi F 771 Radt, now supplemented by col.i of Pap.0xy. inv. 87/110(a), to be published by

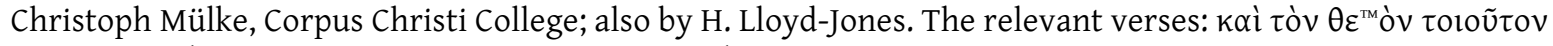

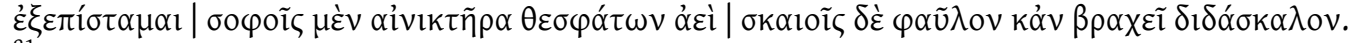

${ }^{21}$ I am grateful to Timothy O'Sullivan for alerting me to these three contexts.

${ }^{22}$ Cf. G. O. Hutchinson, ed., Aeschylus: Septem contra Thebas (Oxford 1985) 46: "We hear of the attack first from the foreknowledge of the absent prophet, then from an eye-witness's report, and finally from the chorus's direct perception."
} 
The poetics of mantic visualization mark not only Aeschylus' Seven against Thebes in particular but also the genre of tragedy in general, the vehicle of which is theatron ( $\theta \dot{\varepsilon} \alpha \tau \rho \circ$ ) 'theater': this noun is derived from the verb theaomai, meaning 'see, visualize', with a suffix tron $\{104 \mid 105\}$ that actually designates the vehicle for the action of that verb. ${ }^{23}$ The mantic

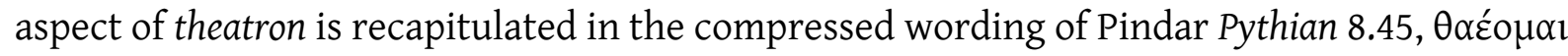

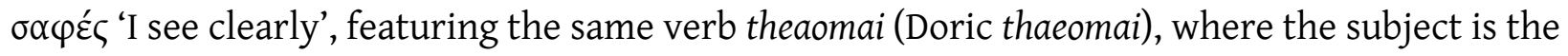
hero Amphiaraus, speaking from the dead as he visualizes the image of the snake on the shield of his son, the hero Alcmaeon.

Not only is the word for 'theater' mantic. There is a word for the professional 'actor' of theater that is mantic as well: it is hupokritēs, derived from hupokrinomai 'respond' in the specific mantic sense of respond to a vision, where the vision is an omen that occurs in "real life" or in a dream. ${ }^{24}$ Of particular interest are idioms referring to the mantic practice of dreaminterpretation or Traumdeutung, such as opsin krinō 'interpret a vision' (Herodotus 1.20.1) and en-hupnion krinō 'interpret a dream' (ibid.: the opsis 'vision' here is equated with the en-hupnion 'dream'; cf. 7.19.1). ${ }^{25}$

To sum up what we have seen so far: both the tragedy of Aeschylus and the epinician of Pindar define themselves as mantic. The explicit theatricality of Aeschylean "neo-epic" and

\footnotetext{
${ }^{23}$ On the mantic connotations of the related forms thea ( $\theta \varepsilon \dot{\alpha} \alpha$ not $\theta \varepsilon \alpha$ ) and theōros ( $\left.\theta \varepsilon \omega \rho o ́ \varsigma\right)$, see Pindar's Homer p. 164. On theatron, see also Herington, Poetry into Drama p. 224: "It is sometimes forgotten that the word and concept theatron was by no means associated only with the drama; quite possibly, indeed, it antedated the drama." He cites the use of the word in Herodotus 6.67.3 with reference to the Spartan festival of the Gymnopaidiai. On Plato's idea of theatrokratia ( $\theta \varepsilon \alpha \tau \rho \circ \kappa \rho \alpha \tau i ́ \alpha)$ 'theatrocracy' as a new cultural force that erodes the differentiations of the old eide ' 'genres' of songmaking and poetry (Laws III 701a), see Pindar's Homer pp. 108-109. A question not addressed by Plato's discussion is this: how does the "theatrocracy" of tragedy as the prime genre of the City Dionysia affect epic as the prime genre of the Panathenaia?

${ }^{24}$ The relevant contexts of hupokritēs and hupokrinomai are collected and analyzed by H. Koller, "Hypokrisis und Hypokrites," Museum Helveticum 14 (1957) 100-107. To be added to his bibliography: G. Thomson, Aeschylus and Athens: A Study of the Social Origins of Drama (2nd ed. London 1946) 181-182; cf. also J. Svenbro, Phrasikleia: An Anthropology of Reading in Ancient Greece (2nd ed. of original 1988 French version, translated by J. Lloyd; Ithaca 1993) 171-173. More on hupokritēs in Pindar's Homer pp. 162-163, 168n95, 376, 379. In a forthcoming work, I analyze a variety of idioms involving hupokrinomai in both mantic and theatrical contexts.

${ }^{25}$ Koller p. 101.
} 
the implicit theatricality of Pindaric "micro-epic" - as compressed in the expression $\theta \alpha \varepsilon$ ć $\alpha_{1}$

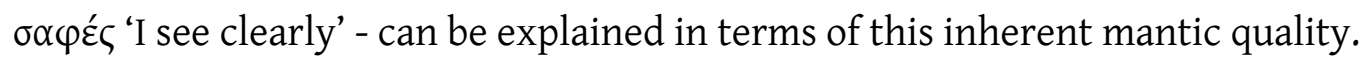

Now we turn to the epic of Homeric poetry. We are about to see that $\{105 \mid 106\}$ epic narrative is not only pervaded by mantic visions: it is actually driven by them. Further, the poetics of mantic visualization can help clarify the theatricality of epic in its own right.

Let us begin with a Homeric example of hupokrinomai, which is a key to understanding the mantic - and theatrical - potential of epic. It will be clear from this example that any given mantic vision has to be performed as a question - either by a character in the narration or simply by the narration itself - so that the interpretation of its "real" meaning may be performed as a response. ${ }^{26}$ The passage in question is Iliad II 228 , where hupokrinomai refers to a hypothetical

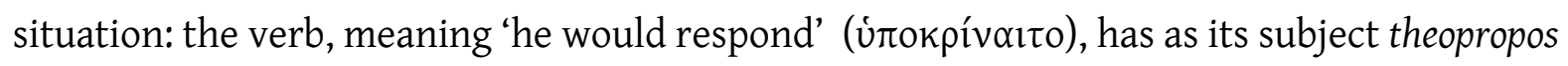
'seer'. The speaker in this context describes the generic theopropos as one who knows sapha

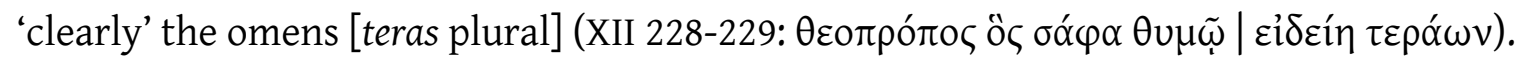

The speaker who is being "quoted" here by the Homeric narrative happens to be the hero Polydamas, a comrade of Hector. Polydamas has just interpreted a teras 'omen' in his own right (XII 209): it is the vision of a drakōn 'snake' (XII 202, 220), who stings an eagle carrying it, in midflight; once stung, the bird drops the snake amidst the ranks of the Trojans and flies off (XII 200-209). This omen is quoted directly by the words of Homeric narrative (again, XII 200209). Then the meaning of these poetic words is interpreted by the likewise poetic words of the hero Polydamas, which are also quoted directly (XII 210-229). It is clear, according to Polydamas, that the Trojans in general and Hector in particular could potentially equate themselves with the snake - and thereby equate the Achaeans with the eagle - if only Hector

\footnotetext{
${ }^{26}$ In the same forthcoming work as mentioned in note 24, I analyze all attested Homeric examples of hupokrinomai.
} 
would heed the omen (again, XII 210-229). ${ }^{27}$ The hero Polydamas is "quoted" as saying, at the conclusion of his words, that these same words of interpretation would be matched by the words of interpretation spoken by a hypothetical seer: the seer 'would respond', as expressed by the verb hupokrinomai in the optative (ن்rokpívalto), the same way as Polydamas has in fact just responded (XII 228-229).

In other words, what the hero here performs in epic corresponds to what a theopropos 'seer' could potentially perform if he responded to the same vision as narrated by epic. Thus epic poetry is declaring its $\{106 \mid 107\}$ control of mantic poetry ${ }^{28}$ The question remains, though, whether the visions of mantic poetry can control epic.

The all-pervasiveness of mantic visualization in Homeric poetry is evident in the foundational teras 'omen' of the Iliad as epic, which takes the form of a primal vision interpreted by the seer Calchas. The Iliad "quotes" the seer himself as saying at II 324: $\dot{\eta} \mu \tilde{i} v \mu \dot{\varepsilon} v$

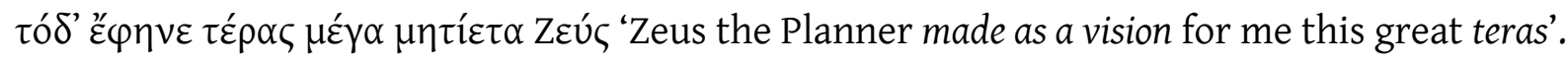
The teras 'omen', which is framed by the narrative of Odysseus (II 284-332) - which in turn is framed by the overall Homeric narrative - is the vision of a drakōn 'snake' (II 308) that first devours eight young birds and then the mother bird (II 303-320). The vision happened in the first year of the Trojan War, during a sacrifice on the occasion of the assembling of Achaean

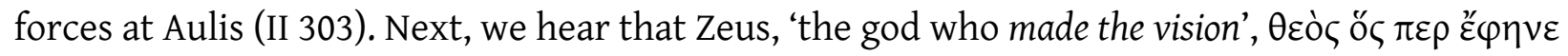
(II 318), proceeded to render this vision permanent and unchanging - by turning the snake into stone (II 319). In the words of Odysseus, the whole vision of the drakōn 'snake' (II 308) is a sēma (II 308), which we may interpret not only as a mental 'sign' but also as a concretized visualization. The petrified vision of the snake becomes a concrete work of the visual arts, a

\footnotetext{
${ }^{27}$ For an alternative situation, where Hector is compared to an eagle, see Iliad XV 690, to be discussed further below.

${ }^{28}$ For a detailed study of representations, in and by the genre of epic, of other poetic genres, see R. P. Martin, The Language of Heroes: Speech and Performance in the Iliad. (Ithaca 1989)
} 
three-dimensional frozen motion picture. It is thereby a permanent monument, a landmark, of the original omen.

Just as this concretized vision of the story of Ilion - and of the Iliad itself - is imagined as unchanging and permanent, so too is the kleos or poetic 'fame' of epic that radiates from the words of the seer Calchas as directly "quoted" by Odysseus in Iliad II 323-332. In the words of

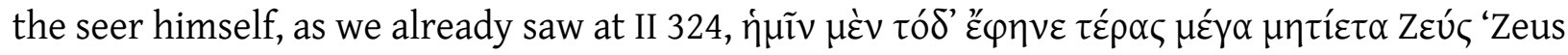
the Planner made as a vision for me this great omen [teras]'. Then Calchas goes on to prophesy that the kleos of this omen [teras] will never perish:

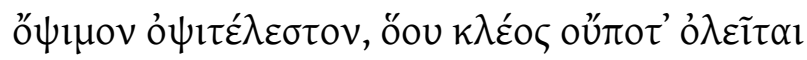

[... this teras], late in coming, late in coming to fulfillment [telos], and its kleos will never perish

Iliad II 325

That was then, at Aulis, in the first year of the Trojan War (Iliad II \{107|108\} 303). Now, as Odysseus is "quoting" back those same words of the seer, it is the ninth year at Troy (II 295). Calchas was saying, back then, in the words that are now being "quoted" by Odysseus (II 323332), that the nine birds are the nine years that the Achaeans will spend at Troy, and that the citadel will now be captured finally in the tenth year. After Odysseus "quotes" these words of

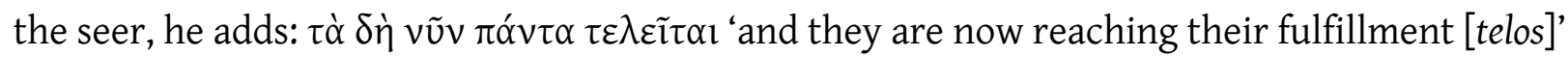
(II 330).

Here the snake is a positive sign for the Achaeans. By contrast, in the earlier example of an omen calling for an act of interpretation as expressed by the mantic word hupokrinomai, we have seen another drakōn 'snake' becoming a negative sign for the Achaeans, insofar as it becomes a potentially positive sign for the Trojans (Iliad XII 202, 220). 
Similarly, the drakōn 'snake' in Pindar Pythian 8.46 is a positive sign for the anti-Theban heroes who are sons of the original Seven against Thebes. In Aeschylus Seven 486-525, by contrast, the complex image of snakes and dragons on the shield of the anti-Theban hero Hippomedon is a decidedly negative sign for the pro-Theban heroes defending the seven gates of Thebes against the same original Seven. I will return to this image at a later point; for now, I simply draw attention to a relevant detail at Seven 503: the anti-Theban hero Hippomedon himself is compared to a drakōn 'snake' who menaces defenseless young birds. We may also compare the choral reference at Seven 291 to the seven anti-Theban heroes as predatory drakontes who prey on defenseless young birds. Moreover, at Seven 381, the anti-Theban hero Tydeus is said to 'roar' (ßoỗ) like a drakōn. In such contexts, the translation 'dragon' is even more appropriate than 'snake'. ${ }^{29}$

On the basis of the comparisons that we have considered so far, I offer this summary: the mantic visions of omens, deeply embedded as they are within the narrative agenda of Homeric poetry, make it clear that the genre of epic itself shares its poetics of visualization with the "neo-epic" of Aeschylus and the "micro-epic" of Pindar. But the argument can be taken further: I would even go so far as to say that the visual worlds of Aeschylus and Pindar can ultimately be described as epic in nature, and that the blazons visualized on the heroic shields of $\{108 \mid 109\}$ their "neo-epic" and "micro-epic" creations are in fact a shining example of epic pure and simple. After all, the most complex and spectacular of all blazons is a creation of epic: it is the Shield of Achilles in Iliad XVIII. The mantic vision of this ultimate Shield is a microcosm that interprets - and is interpreted by - the macrocosm of the epic that frames it. ${ }^{30}$

\footnotetext{
${ }^{29}$ On homologies of snake / dragon in various myths of Indo-European provenience, see C. Watkins, How to kill a dragon: Aspects of Indo-European poetics (New York 1995), especially pp. 448-459 with reference to Typhon. At a later point in this essay, I have more things to say about this "dragon," Typhon.

${ }^{30}$ Nagy, "The Shield of Achilles: Ends of the Iliad and Beginnings of the Polis," New Light on a Dark Age: Exploring the Culture of Geometric Greece (ed. S. Langdon; Columbia, Mo. 1997) 194-207.
} 
The argument can be taken still further: the Shield of Achilles, as an example of an epic sub-genre, is related to the epic sub-genre of the Homeric simile. ${ }^{31}$ Like the Shield, the Homeric simile can function as a "recasting" of mantic visions. ${ }^{32}$ Like the Homeric micro-narratives about the responses of theopropoi 'seers' to omens, Homeric similes become micro-narratives in their own right, deeply embedded within the macro-narratives of the Iliad and odyssey. The mechanism of likening in the simile - that is, of saying that something from the outer frame of the narrative is "like" the inner content of the simile - is an act of interpretation. As such, the Homeric simile can be just as mantic as the response given by a seer to a given vision. What gets interpreted, moreover, is not only the vision of the simile, by way of its connectedness to the outer frame of the macro-narrative, but also the macro-narrative itself, which is deepened and thus enhanced by the embedded mantic vision of the simile's micro-narrative. ${ }^{33} \mathrm{By}$ extension, then, we may even say that epic itself is pervasively mantic by virtue of interpreting - and being interpreted by - similes embedded within its narrative frame.

In this mantic light, let us take one last look at the vision of the shield of Alcmaeon in the "micro-epic" of Pindar's Pythian 8. The visualization of the drakōn, which I have already quoted earlier, is seen as a positive sign in the words of interpretation emanating from the dead seer, which I have also already quoted. This time, however, I will quote simultaneously the vision and the interpretation that immediately precedes it: $\{109 \mid 110\}$

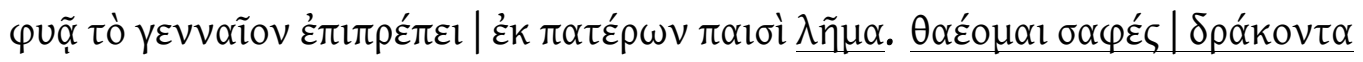

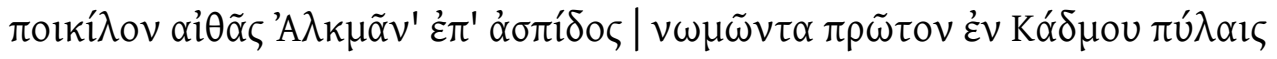

\footnotetext{
${ }^{31}$ L. Muellner, "The simile of the Cranes and Pygmies," HSCP 93 (1990) 59-101, especially p. 91n59, with reference to the explicit likening of the dancing-place on the Shield to the one that Daedalus contrived for Ariadne in Crete (Iliad XVIII 590-592).

${ }^{32}$ I borrow the term from Muellner pp. 98-99.

${ }^{33}$ See especially Muellner p. 68.
} 
By inherited nature, the noble purpose [lēma] shines forth from fathers [pateres]

to sons. I see [thaeomai] clearly [saphes] Alcmaeon, wielding the patterned

[poikilos] snake [drakōn] on his blazing shield, in the forefront of the gates of

Kadmos.

Pindar Pythian 8.44-47

As we can see clearly from the original Greek as printed above, the switch from the interpretation of the vision to the vision itself happens within a single colon and is marked by

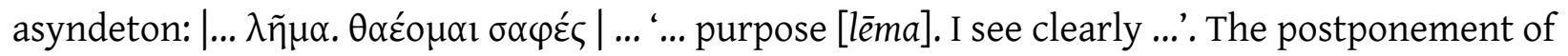
the word that marks the subject of the clause, lema 'purpose', all the way to the end of the clause accentuates the juxtaposition of this key word with the two words that signal the vision itself, thaeomai saphes 'I see clearly'. The juxtaposition is further accentuated by the asyndeton. Just as the sign on the shield gives a positive meaning to the drakon 'snake' in Pindar's Pythian 8 , so also the interpretation by the seer gives a positive meaning to the lemma 'purpose' of the fathers. ${ }^{34}$ This positive meaning resurfaces dramatically near the conclusion of the Pindaric ode, as the voice of the poet declares:

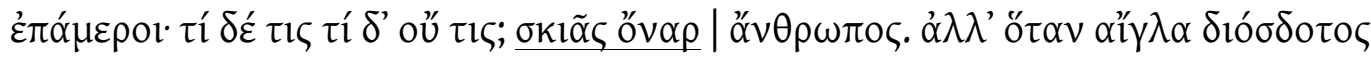

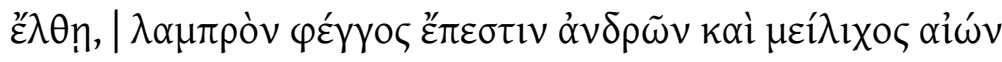

Creatures of a day. What is a someone, what is a no one? Man is the dream of a shade. But when the radiance [aiglēe given by Zeus comes, there is at hand the shining light of men, and the life-force [aiōn] gives sweet pleasure.

Pindar Pythian 8.95-97

\footnotetext{
${ }^{34}$ We may compare the positive meaning of lēma 'purpose' in Aeschylus Seven 616, with reference to Amphiaraus.
} 
Here is what I have already written elsewhere about this passage: $\{110 \mid 111\}$

I interpret skias onar 'dream of a shade' as a recapitulation of the earlier words of the dead Amphiaraus about his living son. In Homeric usage the word skia can designate a dead person. I suggest that the shade of the dead person is literally dreaming - that is, realizing through its dreams - the living person. In other words, the occasion of victory in a mortal's day-to-day lifetime is that singular moment when the dark insubstantiality of an ancestor's shade is translated, through its dreams, into the shining life-force of the victor in full possession of victory, radiant with the brightness of Zeus. It is as if we the living were the realization of the dreams dreamt by our dead ancestors. ${ }^{35}$

The benign vision here of the aigle 'radiance' of Zeus seems to me metonymically connected to (and mantically synchronized with) the radiant vision announced by the seer Amphiaraus when he says clairvoyantly thaeomai saphes 'I see clearly' as he looks out from the shades of the dead and sees the image of the snake on the blazing shield of Alcmaeon. By metonymy, the image of the snake now shines with the radiance of Zeus. To understand the full power of this positive image in Pythian 8, we must now contrast it with the negative image of the snake at Seven 503 and elsewhere $(291,381)$.

As I have noted earlier, drakōn 'snake' is applied at Seven 503 as a simile to describe the anti-Theban hero Hippomedon, who menaces the Thebans just as a snake menaces young birds; moreover, as I have also noted earlier in passing, the blazon on the shield of Hippomedon is itself replete with negative images of snakes and dragons (Seven 486-525). But now we come to a further important detail: the snake on the shield of Hippomedon spews

\footnotetext{
${ }^{35}$ Nagy, Pindar's Homer pp. 195-196. This interpretation is not necessarily at odds with other interpretations that stress the presence of another theme in this passage: that human life is sadly ephemeral (for references, see further at pp. 195 notes 211, 212).
} 


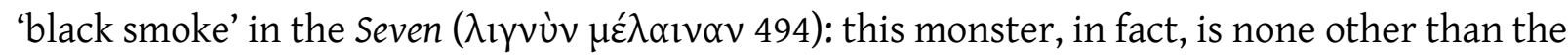
fire-breathing Typhōn (Seven 493 and 511; cf. 517). Typhon's very name derives from the root tuph-, meaning 'smoke' ( $\tau \cup \varphi-) .{ }^{36}$ The legacy of this root tuph- tells its own story: historians of the Greek language have remarked on how far and wide its basic meaning of 'smoke' has spread, generating a spectacular variety of "words relating to obscurity, blindness, or else to the darkening of one's wits, stupidity, or even to becoming $\{111 \mid 112\}$ blind to one's own self, pretension, boasting, vanity. ${ }^{17}$ Such an etymological inventory of Greek words derived from the root tuph-can also serve as a poetic inventory of the negative characteristics of the Seven against Thebes in Aeschylus' drama by that name.

In Pindar's Pythian 8 as well, the image of the Typhon fits these same negative characteristics (lines 15-18), though here the identity of the monster is kept separate from the positive characteristics of the snake featured on the blazing shield of Alcmaeon (lines 45-48). In the Pindaric ode, Typhon is named as the premier example of the kind of personality marked by excessive bia 'violence', matched by correspondingly excessive speech: such a person is megalaukhos 'one who boasts grand things' (line 15). We may compare this word with megal' epeukhetai 'he boasts grand things' at Seven $452{ }^{38}$ such a person deserves to be smitten, says the chorus at 453 , by the divine thunderbolt. ${ }^{39}$

In Pindar's Pythian 8, the negative image of Typhōn is an effective foil for the positive image of the drakōn 'snake' pictured on the blazing shield. The non-vision of the dark Typhon is needed to achieve the vision of the radiant snake. Similarly, the skias onar 'dream of a shade' is

\footnotetext{
${ }^{36}$ P. Chantraine, Dictionnaire étymologique de la langue grecque (Paris 1968-1980).

${ }^{37}$ Ibid.: "d'où les termes relatifs à l'obscurité, la cécité, d'autre part ceux qui expriment l'obscurcissement de l'esprit, la stupidité, enfin ceux qui signifient l'aveuglement sur soi-même, la vantardise, la vanité."

${ }^{38}$ On Hector's hybristic speech-acts involving eukhomai in the Iliad, as at XIII 54, see L. Muellner, The Meaning of

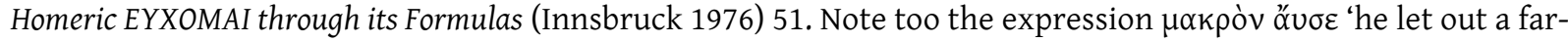
reaching shout' at Iliad V 101, picked up by the participle of eukhomai at V 106 (I owe this reference to Philippe Rousseau).

${ }^{39}$ See also the negative context of eukhomai 'boast' at Seven 633, where it is used synonymously with araomai 'curse'.
} 
a foil for the ultimate aigle 'radiance' of Zeus himself. But there is more to it: the seer sees the radiance from the shades, and in fact he is the shade. In my interpretation, the 'dream of a shade' is the actual medium of vision, of visualization, for the victorious athlete in the present to be seen by his ancestors from the past.

In order to validate this interpretation of the Pindaric expression skias onar 'dream of a shade', I still need to find some kind of formal parallel in the traditional poetic repertoire of epic themes. Such a parallel exists, I propose, in Aeschylus' Seven. In this case, however, the context is decidedly malign, not benign. In response to the mutual killings of Eteocles and Polyneices, the choral song of the Theban $\{112 \mid 113\}$ women speaks of 'the Lady, the shade [skia]

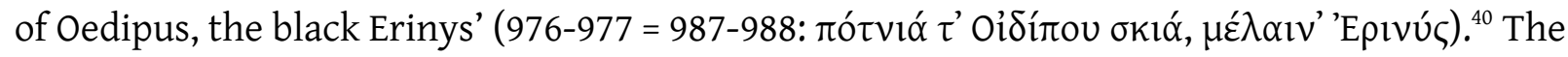
skia 'shade' of the dead Oedipus is pictured here as the living Fury that becomes the death of the hero's two accursed sons.

The question remains: where, then, is the dream of this negative shade? At an earlier moment in the Seven, Eteocles speaks of the ara 'curse' of his father Oedipus (695), and the chorus speaks of this curse as an Erinys (700) that needs to be exorcised with the help of the gods (699-701); then there is talk of an unnamed force to which the chorus refers simply as daimōn 'daemon' (705), an entity that needs to be averted from acting on his lèma 'purpose'

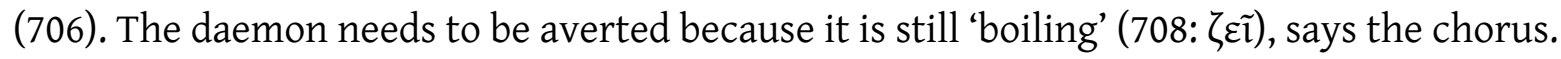
Eteocles responds:

\footnotetext{
${ }^{40}$ I follow most editors by printing $\mu \varepsilon \dot{z} \alpha \_v v$ ' at Seven 977, reflecting Porson's emendation of the manuscript reading

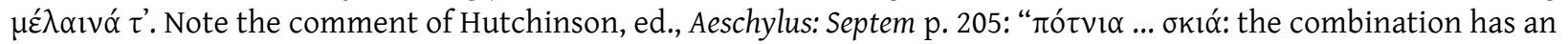
air of paradox. бkió normally suggests weakness and insignificance, even when used of the dead. It is not absolutely necessary to identify the ghost [of Oedipus] with the Erinys by placing a weak stop, not a strong, after

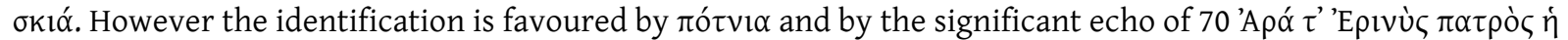
$\mu \varepsilon \gamma \alpha \sigma \theta \varepsilon v \eta ́$ c. Cf. [Apollonius of Rhodes] 3.704." Albert Henrichs reminds me that, in Sophocles Oedipus at Colonus

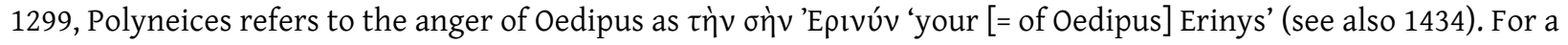
striking parallel to Seven 976-977 = 987-988, see also Sophocles Oedipus Tyrannus 417-419; I owe this reference to Charles Segal.
} 


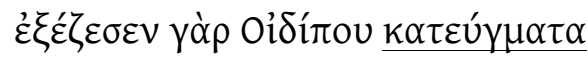

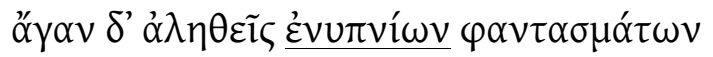

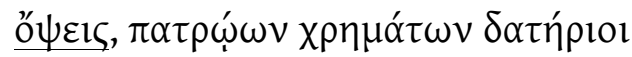

Yes, it [the daimōn] boiled over in wrath with the curses [kateugmata, from eukhomai $]^{41}$ of Oedipus!

All too true are the visions [opsis plural] of apparitions-in-dreams [en-hupnia], ${ }^{42}$

- visions of dividing the father's property.

We may note too the choral description of the same Erinys at Seven 720-726: here the Fury, as the realization of the katarai 'curses' (725) $\{113 \mid 114\}$ of Oedipus, is described as 'a malign mantis who is absolutely true, the father's prayed-for [euktaia, from eukhomai] Erinys' (722-723:

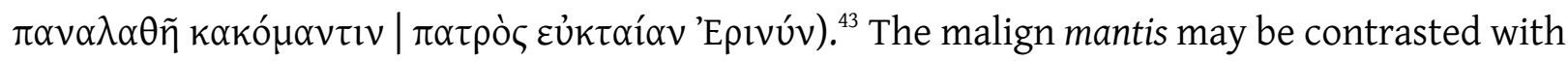
the benign mantis of Pythian 8. Likewise, the malign lèma of the malign daemon at Seven 706 may be contrasted with the benign lemma of the benign ancestors in Pythian $8.45 .{ }^{44}$ The Fury of

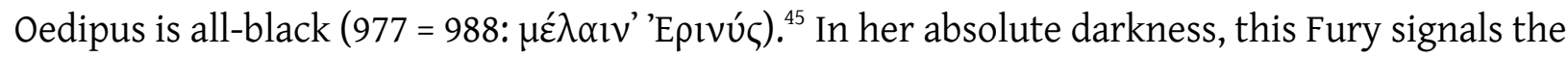
total eclipse of radiance, which may be contrasted with the shining image of the radiant snake envisioned by Amphiaraus on the blazing shield of Alcmaeon in Pythian 8 (46).

\footnotetext{
${ }^{41}$ For other examples of negative eukhomai see note 39.

${ }^{42}$ The adjectival en-hupnia 'in-dreams' describes the phantasmata 'apparitions'.

${ }^{43}$ In the Seven, the malign prophetic contexts of araomai 'curse' are generally parallel to the benign (or neutral) contexts of eukhomai 'pray'; see note 39 above. With specific reference to the curse of Oedipus, the diction of the Seven corresponds closely to the diction that we find in the fragments of the epic Thebaid: PEG F 1 [=EGF F2].7-8, on

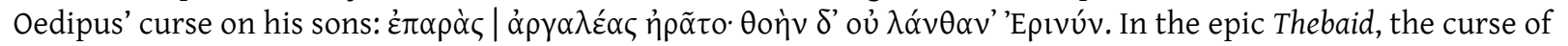
Oedipus is also expressed by way of eukhomai: PEG [and EGF] F 3.3 عũk $\tau$. With further reference to Seven 722-713, Charles Segal has shown me a striking point of comparison in Sophocles Oedipus Tyrannus: the chorus asserts that the discourse of Teiresias is aletthes 'true' at 299, and the seer himself reaffirms the assertion at 461; what follows at 463-511 is an ode about the mantic voice emanating from the god.

${ }^{44}$ The climactically negative humnos of the Erinus at Seven 867 may be contrasted with the positive humnos in Pythian 8.57, as discussed at note 19 .

${ }^{45}$ Likewise, the ara 'curse' of Oedipus is all-black: Seven $695,832$.
} 
The system of complementarity in the deployment of negative and positive images for snakes in Pindar's Pythian 8 and Aeschylus' Seven brings us back, one last time, to the corresponding epic system of complementarity in Homeric poetry. As we have seen, the vision of the snake that menaced and then devoured the defenseless birds in Iliad II was ultimately positive for the Achaeans - that is, after Calchas the seer interpreted it for them. As for the vision of the snake that stung the eagle in Iliad XII, it was positive for the Trojans - that is, it was potentially positive, after Polydamas interpreted it for Hector. But the point is, this same image of snake and bird could ultimately become negative for the Trojans if they failed to heed its mantic interpretation. From the macro-narrative of the Iliad, we do in fact know that Hector fails to heed that interpretation: he consistently refuses to stay on the defensive, unlike the snake that stung the eagle. Instead, Hector consistently goes $\{114 \mid 115\}$ on the offensive, despite the repeated warnings of the clairvoyant Polydamas.

At Iliad XV 690, a climactic moment in the course of Hector's playing the part of attacker instead of defender, he is actually given a simile that likens him to an eagle instead of a snake, and the epithet of this eagle is aithon 'blazing' ${ }^{46}$ We may compare the epithet of the shield that pictures the snake in Pindar Pythian 8.46: aith $\bar{a}$ 'blazing'. I see at work here a metonymy: the blazing of the shield is linked with the blazing of the snake. We may compare also the expression aithōn ... lèma 'blazing in purpose' in Aeschylus Seven 448, describing the Theban hero Polyphontes when he faces his Argive opponent, the hero Kapaneus; as the words of Eteocles prophesy, the fire-bearing thunderbolt of the gods awaits Kapaneus (Seven 444-445). Again I see a metonymy: the blazing purpose of Polyphontes is linked with the blazing force of the divine thunderbolt, which will smite Kapaneus. Clearly, the epithet aithōn ... lèma 'blazing in purpose' works for Polyphontes.

\footnotetext{
${ }^{46}$ For more on the narrative tension created by the anomalous context of this simile, see Muellner, "The Simile of the Cranes and Pygmies" pp. 69-72.
} 
Will the simile of the eagle envisioned as aithōn 'blazing' at Iliad XV 690 similarly work for Hector? The simile is applied at a climactic point of the narrative: Hector is on the attack, moving toward the Achaeans as they stand guard over their ships on the shores of the Hellespont, and at this very moment the hero of the Trojans is compared to an eagle swooping down on flocks of defenseless geese, cranes, and swans as they feed on vegetation growing on the banks of a river (XV 690-691). The problem is, the Achaeans cannot be visualized as defenseless birds except in such a moment of testing, glimpsed by the micro-narrative, and that fleeting moment will ultimately be overwhelmed by the macro-narrative. ${ }^{47}$ The other problem is that the image of an attacking eagle suits Hector's epic identity not nearly as well as a defending snake. Ultimately, Hector would have been better off if he had imagined himself as a snake caught in the claws of an eagle: the omen of the bird stung by the snake had made that clear. Even if the epithet aithōn works for the eagle, the image of the eagle in this simile fails to work for Hector. This image is intended to fail in the macro-narrative of epic.

I conclude this essay by asking a similar question about the images on the shields pictured in the "micro-epic" of Pindar's Pythian 8 and in $\{115 \mid 116\}$ the "neo-epic" of Aeschylus' Seven: do they work for the heroes they signify? In other words, is epic signification intentional?

In the case of Pindar, the response is simple: yes. As I contemplate the blazon on the shield of Alcmaeon in Pythian 8, I see no contradiction of the art of epic imagery as idealized in that ultimate blazon, the shield of Achilles in Iliad XVIII. Pindar's poetics are intentionally true to the Homeric ideal writ large, and I think it cannot be an accident that the last word of his Pythian 8 is "Achilles." The "micro-epic" lemma 'purpose' (or 'will') of the ancestors in Pindar's Pythian 8 seems to me linked with the "macro-epic" boule 'will' of Zeus in Iliad I 5. In the case of Aeschylus, by contrast, the response has to be far more complex: here we have to reckon with

${ }^{47}$ Ibid. 
the "theatrocracy" of tragedy as a genre, which keeps testing the limits of epic as a genre. ${ }^{48}$ The poetics of Aeschylus' "neo-epic" verge on becoming the "non-epic" or even the "antiepic."

To bring up the topic of non-epic imagery in the Seven goes far beyond the limits of this essay - especially at this point, nearing the very end. Still, I need examples to show that the "neo-epic" of tragedy as genre is in fact open-ended. Here, then, are three such examples, confined to the smallest possible space for contemplating them.

First, there is the shield of the anti-Theban hero Eteoclus, bearing the image of an unnamed man attacking an unnamed city (Seven 456-471). ${ }^{49}$ Eteoclus will fight the Theban hero Megareus, a descendant of the Spartoi (474). ${ }^{50}$ If Megareus wins, says Eteocles, then he will have captured two men and a city (477-479). This vision is a mirror image of what would happen if Megareus and Thebes were captured: instead, Megareus will capture the named man and, in addition, the unnamed man and the unnamed city in the picture, since the picture is on the captured shield. To be sure, anonymity can be used in epic too for the shifting of signifiers, as we can see from the two unnamed cities on the Shield of Achilles in Iliad XVIII. But the difference is, we do $\{116 \mid 117\}$ not expect epic to split the signifier from its signified, as we see in the doubling of the captured men imagined by Eteocles.

Second, there is the shield of Polyneices, with its climactic diploun sēma 'double sign' (Seven 643). Here we see the image of an anonymous gune 'woman' (646) who leads by the hand an anonymous man toward a citadel. Polyneices interprets the gunē as the goddess of justice, Dikē: she will install him, he boasts, as the rightful ruler of the polis (646-648). In the Seven, the word

\footnotetext{
${ }^{48}$ See note 23 for more on the "theatrocracy" of drama over other genres in general.

${ }^{49}$ As a name, Eteoklos (Eteoclus) is a morphological variant of Eteokleēs (Eteocles). As a character, the anti-Theban Eteoclus is a thematic variant of the Theban Eteocles by virtue of being substituted for the epic Adrastos: see Zeitlin, Under the Sign of the Shield p. 78.

${ }^{50}$ The Spartoi, descendants of the Dragon's teeth, are also the ancestors of the Theban hero Melanippos (412). Thus two of the seven Theban defenders are connected to "snakes."
} 
gune applies generically to everyday 'woman', as at 197, 200, 256, 645, 712. In the last of these verses, the chorus of women tries to dissuade Eteocles from fighting the mutually fatal fight with Polyneices: they say peithou gunaixi 'obey the women'. We may contrast 225, where Eteocles speaks of the goddess Peitharkhia, who is the very idea of 'obeying authority', as the wife of the Sōtēr 'savior'. Finally, there is Antigone as generic gunē at 1038. The question is, then: whom to obey, the authority of the state or the women? ${ }^{51}$ If the chorus of women is right and Eteocles (along with Polyneices) is wrong in not 'obeying the women', then perhaps the anonymous woman pictured on the shield of Polyneices may remain simply that, a generic woman. Or at least she may become Antigone in her role as generic woman. As for the anonymous man whom she leads by the hand, he too may remain simply that, a generic man. Or at least he may become the citizen of a new polis that transcends the old citadel. Such doubling of what is human, by keeping the generic separate from the heroic, seems antithetical to epic.

Third, there is the shield of the seer Amphiaraus. It has no sēma on it (591), since he wants to be the best, not just to seem the best (592). Such splitting between hero and heroic image seems antithetical to epic. The mantic words of Amphiaraus, "quoted" at 580-589, can now take the place of an epic vision that cannot be there because it cannot be real. The new dramatic imagination is seeking to differentiate itself from an older epic vision. We see another kind of differentiation in the more old-fashioned "quotation" of Amphiaraus' mantic words in Pindar $\{117 \mid 118\}$ Pythian 8.44-55, picturing the shield of Alcmaeon. The image on this shield, that radiant snake, is seen as real not only because it had been heard in the epic of heroes. More

\footnotetext{
${ }^{51}$ In the Seven, 'obeying' a woman is imagined differently from 'obeying' a man in authority. For men in this drama, the basis of persuasion is the threat of violence; for women, it is the fear and pity caused by the violence, especially as experienced by women captured in war (cf. 253, 326-327, 338ff, 764-765). Further, the emotions of fear and pity are equated with expressions of women's songs, especially laments. We may contrast the command of Eteocles to the women of Thebes at 232, 242-243: do not lament! (See also the contexts of philostonōs at 279 and of merimnai at $289,843,849$.)
} 
than that, this image is seen as real because it had once been seen personally by the hero of epic himself, and thus the vision of its reality may keep shining through from far away, far off in the realms of the insubstantial shade that dreamed it. 